\title{
Performance Evaluation of Three Egyptian Cotton Genotypes under Different Thermal Units Related to Different Planting Dates
}

\author{
A.H.A. Mahdi (1)\#, H.S. Khalifa( ${ }^{(2)}$, R.S. Taha ${ }^{(3)}$ \\ (1) Agronomy Department, Faculty of Agriculture, Fayoum University, Fayoum 63514, \\ Egypt; ${ }^{(2)}$ Cotton Research Institute, Agriculture Research Center, Giza 12619, Egypt; \\ (3) Botany Department, Faculty of Agriculture, Fayoum University, Fayoum 63514, \\ Egypt.
}

$\mathbf{F}$ ARMERS are often unable to determine the effect of different environmental stress on growth and development of cotton plants. So, the experiment conducted through a wide range of thermal changes by planting cotton at different dates. This work aimed to performance evaluation of some Egyptian cotton genotypes i.e., Giza 90, Giza 90 x Aust. and Giza 95 under different thermal units related to different planting dates i.e., $1^{\text {st }}$ April, $16^{\text {th }}$ April and $1^{\text {st }}$ May. The results demonstrated that late planting led to decreasing plant height, number of leaves/ plant and leaf area/plant. Number of fruiting/plant increased in early planting due to lowered of node of the first sympodium and inducing early balance between vegetative and fruiting. Low temperatures at the beginning of the season and the decrease the number of thermal units in early planting led to increase concentration of chlorophyll $a, b$ and carotenoids in leaves and increase earliness index. Late planting produced the first flower and first open boll in shorter period as compared to early planting, but it consumed more number of heat units. Yield and its quality have increased in early planting where utilized the heat units in producing the highest number of open bolls and enhance cotton fiber properties conversely late planting which used most of the heat units in increasing the vegetative growth. Giza 95 surpassed in all studied characters compared to other genotypes. The efficiency of Egyptian cotton genotypes particularly Giza 95 for use of air thermal units increased in early planting. From the results above, it could be concluded that early planting maximized of the use of heat units by increasing the efficiency use of air thermal units through the growing season which lowered the amount of heat units for necessary production one boll.

Keywords: Genotypes, Thermal units, Planting dates, Cotton.

\section{Introduction}

Cotton is a perennial tropical crop of undetermined growth, grownas an annual crop for lint, oil and animal feed (Constable \& Bange, 2015). Egyptian cotton (Gossypium barbadense L.) is known as extra- long staple and is famous in the world for their high fiber quality. It is plays a prominent role in supporting the economy of country. Cotton is important for food Egyptians (oils), feed (animal's cake) and fiber for both export and local textile industry (Mahdy et al., 2017).

Climate changes have affect crop growth interactively, sometimes resulting in unexpected responses to prevailing conditions. Many factors, such as length of the growing season, climate (including solar radiation, temperature, light, wind, rainfall and dew), cultivar, availability of nutrients and soil moisture, pests and cultural practices affect cotton growth (Sawan, 2017).

Air temperature is one of the important factors which affect the rate of growth and development of cotton plants. The lower and upper developmental threshold ranging between $15-37^{\circ} \mathrm{C}$ (Gipson \& Ray, 1970). Below $15^{\circ} \mathrm{C}$ the development ceases sharply and above $37^{\circ} \mathrm{C}$ the development tended to decrease. However, this poses an interesting situation for cotton growers in Egypt, as it is common to exceed these optimal temperatures in the summer.

Moreover, the high temperatures reduce the interval between flowering and boll opening, shortening the time to maturity. As well as,

${ }^{\#}$ Corresponding author email: aha02@fayoum.edu.eg

DOI: 10.21608/agro.2019.12006.1162

C2019 National Information and Documentation Center (NIDOC) 
high temperatures can decrease photosynthesis and increase respiration, leading to reduced seed production, reduced lint development and unexpectedly lower yield. In the same order, high temperatures can reduce boll growth and retention due to lower net photosynthesis following reduced growth and respirationat night, which suppresses sink demand and inhibits the forming of starch in leaves (Yeates et al., 2013).

Due its indeterminate growth habit, the crop shows morphological adaptations to its growing environment such as modification in canopy structure (Mao et al., 2014). Cotton planting is a laborious practice due to transplantation into open field ( $\mathrm{Lu}$ et al., 2017). Planting time is a major agronomic factor that effect growth and yield (Ullah et al., 2015). As, considered one of the predictable factors i.e., occur in systematic manner and under human control. So, through the different planting dates can expose the cotton plants to different temperature. Therefore, optimum sowing time determination is of utmost importance for high yield and quality cotton.

Cotton genotypes having a wide range of adoptability, needs different total number of cumulative heat units (CHU) or growing degree days (GDD) for their growth, development, yield and maturity. The CHU or GDD is the most common index used to estimate the development of a plant. This heat unit's accumulation determines the crop maturity along with the end product quality (Ullah et al., 2015). As, the rate of plant growth is mainly temperature driven thus the gap between the actual and potential yield needs to be closed via modeling of the impact of temperature variation on yield and quality of genotypes.

In this context, this investigation was carried out to study the impact of air thermal units through different planting dates on yield and its components and determine the efficiency utilization of cotton plants for air thermal units in some Egyptian cotton genotypes planted at different times. These data will provide crop management guidelines to cotton growers.

\section{Materials and Methods}

Plant material, growing conditions, experimental design and treatments

Two uniform field trials were conducted at Sids Agricultural Research Station, BaniSwef Governorate, Middle Egypt during 2017 and 2018 seasons. The main aim was to study the effect of three planting dates (i.e., $1^{\text {st }}$ April 1, $16^{\text {th }}$ April and $1^{\text {st }}$ May) on yield and its components of as an indicator to create difference in temperature for growth, development and maturity, thus giving a wide range of temperature from planting till maturity in three Egyptian cotton genotypes (i.e., Giza 90, Giza 90 x Aust. and Giza 95). A split plot design arranged in randomized complete blocks with three replicates was used where, Genotypes were considered as the main plot while the sub plot was designated to planting dates. Each experimental plot contained 5 ridges at width was $60 \mathrm{~cm}$ and its length was $4 \mathrm{~m}$. Seeds obtained Cotton Research Institute, Agricultural Research Centre, Giza, Egypt, were sown at the rate of $30 \mathrm{~kg} / \mathrm{fed}$ in hills $20 \mathrm{~cm}$ apart on one side of the ridge. Cultural management practices such as irrigation, weeding, hoeing, thinning and pesticide application were implemented to reduce competition for nutrient, light and water for a better crop stand.

During soil preparation and plant growth, the soil was supplemented with the full dose of $\mathrm{N}$ $(70 \mathrm{~kg} /$ fed ammonium nitrate $33.5 \% \mathrm{~N})$ with lime at 2 equal doses, the first applied after thinning just before the second irrigation and the second applied before the third irrigation, $\mathrm{P}(150 \mathrm{~kg} / \mathrm{fed}$ calcium superphosphate $15.5 \% \mathrm{P}_{2} \mathrm{O}_{5}$ ) during land preparationand $\mathrm{K}(50 \mathrm{~kg} /$ fed potassium sulphate $48 \% \mathrm{~K}_{2} \mathrm{SO}_{4}$ ) before the first irrigation according to the recommendations of the Ministry of Agriculture and Land Reclamation.

\section{Meteorological data}

Monthly maximum and minimum air temperature and relative humidity in the two growing seasons are presented in Table 1. Meteorological data was obtained from Directorate of Agriculture in Bani-Swef Governorate. The heat units (HU) were calculated according to Young et al.(1980) equation as follows:

$$
\begin{aligned}
& \mathrm{HU}=\text { Mean daily temperature }-\mathrm{K} \\
& \left(\mathrm{K}=\text { zero growth }=12.8^{\circ} \mathrm{C}\right)
\end{aligned}
$$

The efficiency use of thermal heat units by cotton plants estimated by the following equation referred by Emara (2012). 


\section{Total heat units through the whole season}

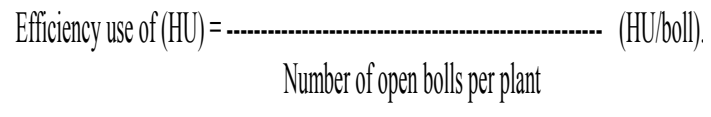

\section{Growth attributes}

Plant height was measured using a meter scale. Number of leaves per plant and number of fruiting per plant were counted. Using a graph sheet, leaf areas were measured manually where the squares covered by the leaf were counted.

\section{Leaf Photosynthetic pigmentconcentrations}

The photosynthetic pigments (i.e., chlorophyll $a$, chlorophyll $b$ and carotenoids in $\mathrm{mg}^{-1} \mathrm{FW}$ ) were estimated by the spectrophotometric method recommended by Lichtenthaler (1987). Leaf samples $(0.3 \mathrm{~g}$ from each replicate of each treatment $(\mathrm{n}=9)$ were homogenized in $50 \mathrm{ml} 80 \%$ $(\mathrm{v} / \mathrm{v})$ acetone and centrifuged at $10,000 \times \mathrm{g}$ for $10 \mathrm{~min}$. The absorbance of each acetone extract was measured at 665,649 , and $440 \mathrm{~nm}$ using a UV160A UV-visible spectrophotometer (Shimadzu, Kyoto, Japan).

\section{Earliness parameters}

Node of the first sympodium, days to first open flower and crackle first boll were recorded. In addition earliness index was calculated according to the following equation:

Earliness index $=\frac{\text { Seed cotton yield of the first pick }(\mathrm{kg})}{\text { Total seed cotton yield }(\mathrm{kg})}$

\section{Yield and its components}

At harvest, ten guarded plants from each plot were randomly chosen from the central ridge to determine number of open bolls per plant and boll weight. Total seed cotton yield of each plot in kilograms (including 10 plant subsamples) was then transformed to kentars per feddan and ginned to determine the seed cotton yield per feddan. Lint percentage was calculated according to the following equation:

$$
\text { Lint percentage }=\frac{\text { Weight of lint cotton }}{\text { Weight of seed cotton }}
$$

\section{Fiber properties}

A sample of $30 \mathrm{~g}$ of lint was taken where the following fiber properties were recorded: Upperhalf mean length (U.H.M.L.) (mm). Fiber uniformity index. Fiber strength ( $g /$ tex). Micronair value. HVI instrument system was used to determine fiberaccording to ASTM: D- 460405 (ASTM, 2005).

\section{Statistical analysis}

All data were subjected to analysis of variance (ANOVA) for a split plot arranged in randomized complete blocks design, after testing for homogeneity of error variances according to the procedure outlined by Snedecor \& Cochran (1990). Combined analysis of data of the two seasons was conducted and significant differences between treatments were compared at $\mathrm{P} \leq 0.05$ by Duncan's multiple range test.

\begin{tabular}{|c|c|c|c|c|c|c|c|c|}
\hline \multirow{2}{*}{ Month } & \multicolumn{4}{|c|}{2017} & \multicolumn{4}{|c|}{2018} \\
\hline & $\operatorname{Max}^{\circ} \mathbf{C}$ & $\operatorname{Min}{ }^{\circ} \mathbf{C}$ & Mean ${ }^{\circ} \mathrm{C}$ & RH \% & $\operatorname{Max}^{\circ} \mathbf{C}$ & $\operatorname{Min}{ }^{\circ} \mathbf{C}$ & Mean ${ }^{\circ} \mathrm{C}$ & RH \% \\
\hline April & 23.07 & 15.03 & 19.05 & 74.01 & 24.11 & 16.78 & 20.45 & 76.43 \\
\hline May & 28.09 & 17.11 & 22.6 & 81.63 & 29.41 & 19.01 & 24.21 & 83.35 \\
\hline June & 32.27 & 21.05 & 26.66 & 67.95 & 33.13 & 22.97 & 28.05 & 69.17 \\
\hline July & 35.43 & 25.89 & 30.66 & 63.33 & 36.73 & 27.17 & 31.95 & 64.35 \\
\hline August & 31.55 & 23.09 & 27.32 & 69.85 & 33.05 & 25.03 & 29.04 & 71.32 \\
\hline September & 29.57 & 21.15 & 25.36 & 73.53 & 30.65 & 23.01 & 26.83 & 75.45 \\
\hline October & 27.53 & 16.13 & 21.83 & 70.97 & 29.31 & 17.91 & 23.61 & 71.75 \\
\hline Mean & 29.64 & 19.92 & 24.78 & 71.61 & 30.91 & 21.70 & 26.31 & 73.12 \\
\hline
\end{tabular}

TABLE 1. Monthly weather data at Bani-Swef, Egypt during 2017 and 2018. 


\section{Results}

\section{Meteorological data}

Mean air temperature was higher during seedling establishment, vegetative growth and remained relatively lower during reproductive periods of both years (Table 1). On average, 2017 was relatively cooler than 2018. Relative humidity was associated with air temperatures during different plant growth stages. It was low during early growth phases and increased as canopy gets closer.

\section{Growth characteristics of Egyptian cotton} genotypes

As shown in Table 2 all growth characteristics (i.e., plant height, number of leaves per plant, number of fruiting per plant and leaf area per plant) were significantly influenced by planting dates and genotypes. Cotton plants sown on $1^{\text {st }}$ April significantly increased in the above growth characteristics by $4.8 \& 10.0 \%, 18.5 \& 44.3 \%$, $23.4 \& 36.6 \%$ and $9.9 \& 27.5 \%$, respectively for Giza 90 ; by $6.5 \& 9.9 \%, 13.1 \& 35.2 \%, 19.5 \&$ $41.2 \%$ and $11.3 \& 25.5 \%$, respectively for Giza
90 x Aust. and by $5.4 \& 7.7 \%, 29.5 \& 53.2 \%, 13.4$ $\& 32.3 \%$ and $11.7 \& 22.7 \%$, respectively for Giza 95 compared to plants sown on $16^{\text {th }}$ April and $1^{\text {st }}$ May. For genotypes, there was significant growth characteristics increases in Giza 95 compared to those in Giza 90 x Aust. and Giza 90.

Leaf photosynthetic pigment concentrations of Egyptian cotton genotypes

The data recoded in Table 3 show that planting dates and genotypes caused significant effect on concentration of chlorophyll $a$, chlorophyll $b$ and carotenoids in the leaves of cotton plants. Crop planted on $1^{\text {st }}$ April showed significant increases in the above photosynthetic pigments concentrations by $30.1 \& 48.7 \%, 30.9 \& 49.1 \%, 14.8 \& 34.8 \%$, respectively for Giza 90 ; by $22.1 \& 56.6 \%, 20.0 \&$ $53.0 \%$ and $38.7 \& 72 \%$, respectively for Giza $90 \mathrm{x}$ Aust. and by $18.2 \& 43.8 \%, 21.4 \& 46.7 \%$ and 30.8 \& $64.4 \%$, respectively for Giza 95 compared to crop planted on $16^{\text {th }}$ April and $1^{\text {st }}$ May. Regarding genotypes, there were significant increases in photosynthetic pigment concentrations of Giza 95 compared to Giza 90 x Aust. or Giza 90.

TABLE 2. Effect of planting dates in combination with genotype on growth attributes of three Egyptian cotton genotypes.

\begin{tabular}{|c|c|c|c|c|c|}
\hline $\begin{array}{l}\text { Treatments } \\
\text { genotypes } \\
\text { (G) }\end{array}$ & $\begin{array}{l}\text { Planting dates } \\
\text { (D) }\end{array}$ & $\begin{array}{l}\text { Plant height } \\
\text { (cm) }\end{array}$ & $\begin{array}{c}\text { No. of leaves/ } \\
\text { plant }\end{array}$ & $\begin{array}{c}\text { No. of fruiting/ } \\
\text { plant }\end{array}$ & $\begin{array}{l}\text { Leaf area/plant } \\
\qquad\left(\mathbf{d m}^{2}\right)\end{array}$ \\
\hline \multirow{4}{*}{$\mathrm{G}_{1}$} & $\mathrm{D}_{1}$ & $133.35 \mathrm{a}$ & $39.13 \mathrm{a}$ & $13.73 \mathrm{a}$ & $32.01 \mathrm{a}$ \\
\hline & $\mathrm{D}_{2}$ & $127.21 \mathrm{~b}$ & $33.03 \mathrm{~b}$ & $11.13 \mathrm{~b}$ & $29.13 \mathrm{~b}$ \\
\hline & $\mathrm{D}_{3}$ & $121.23 \mathrm{c}$ & $27.11 \mathrm{c}$ & $10.05 \mathrm{~b}$ & $25.11 \mathrm{c}$ \\
\hline & Mean & 127.26 C & $33.09 \mathrm{C}$ & $11.64 \mathrm{~B}$ & $28.75 \mathrm{C}$ \\
\hline \multirow{4}{*}{$\mathrm{G}_{2}$} & $\mathrm{D}_{1}$ & $139.75 \mathrm{a}$ & $41.97 \mathrm{a}$ & $15.55 \mathrm{a}$ & $35.11 \mathrm{a}$ \\
\hline & $\mathrm{D}_{2}$ & $131.23 \mathrm{~b}$ & $37.11 \mathrm{~b}$ & $13.01 \mathrm{~b}$ & $31.55 \mathrm{~b}$ \\
\hline & $\mathrm{D}_{3}$ & $127.17 \mathrm{c}$ & $31.05 \mathrm{c}$ & $11.01 \mathrm{c}$ & $27.97 \mathrm{c}$ \\
\hline & Mean & $135.49 \mathrm{~A}$ & $36.71 \mathrm{~B}$ & 13.19 B & 31.54 B \\
\hline \multirow{4}{*}{$\mathrm{G}_{3}$} & $\mathrm{D}_{1}$ & $143.11 \mathrm{a}$ & $49.23 \mathrm{a}$ & $17.13 \mathrm{a}$ & $39.13 \mathrm{a}$ \\
\hline & $\mathrm{D}_{2}$ & $135.73 \mathrm{~b}$ & $38.03 \mathrm{~b}$ & $15.11 \mathrm{~b}$ & $35.03 \mathrm{~b}$ \\
\hline & $\mathrm{D}_{3}$ & $132.93 \mathrm{~b}$ & $32.13 \mathrm{c}$ & $12.95 \mathrm{c}$ & $31.89 \mathrm{c}$ \\
\hline & Mean & $137.26 \mathrm{~A}$ & $39.80 \mathrm{~A}$ & $15.06 \mathrm{~A}$ & $35.35 \mathrm{~A}$ \\
\hline
\end{tabular}

Mean values in the same column for each trait with the same lower small or upper bold-case letters are not significantly different by Duncan's Multiple Range Test at $P \leq 0.05 . G_{1}=$ Giza 90, $G_{2}=$ Giza 90 x Aust., $G_{3}=$ Giza 95, $D_{1}=1^{\text {st }}$ April, $D_{2}=16^{\text {th }}$ April, $D_{3}=1^{\text {st }}$ May. 
TABLE 3. Effect of planting dates in combination with genotype on leaf photosynthetic pigments concentrations of three Egyptian cotton genotypes.

\begin{tabular}{|c|c|c|c|c|}
\hline $\begin{array}{l}\text { Treatments } \\
\text { genotypes (G) }\end{array}$ & Planting dates (D) & $\begin{array}{c}\text { Chlorophyll } a \\
\text { (mg/g FW) }\end{array}$ & $\begin{array}{c}\text { Chlorophyll } b \\
\text { (mg/g FW) }\end{array}$ & $\begin{array}{c}\text { Carotenoids } \\
\text { (mg/g FW) }\end{array}$ \\
\hline \multirow{4}{*}{$\mathrm{G}_{1}$} & $\mathrm{D}_{1}$ & $4.15 \mathrm{a}$ & $4.07 \mathrm{a}$ & $0.31 \mathrm{a}$ \\
\hline & $\mathrm{D}_{2}$ & $3.19 \mathrm{~b}$ & $3.11 \mathrm{~b}$ & $0.27 \mathrm{~b}$ \\
\hline & $\mathrm{D}_{3}$ & $2.79 \mathrm{c}$ & $2.73 \mathrm{c}$ & $0.23 \mathrm{c}$ \\
\hline & Mean & $3.38 \mathrm{C}$ & $3.30 \mathrm{C}$ & $0.26 \mathrm{C}$ \\
\hline \multirow{4}{*}{$\mathrm{G}_{2}$} & $\mathrm{D}_{1}$ & $5.09 \mathrm{a}$ & $4.91 \mathrm{a}$ & $0.43 \mathrm{a}$ \\
\hline & $\mathrm{D}_{2}$ & $4.17 \mathrm{~b}$ & $4.09 \mathrm{~b}$ & $0.31 \mathrm{~b}$ \\
\hline & $\mathrm{D}_{3}$ & $3.25 \mathrm{c}$ & $3.21 \mathrm{c}$ & $0.25 \mathrm{c}$ \\
\hline & Mean & $4.63 \mathrm{~B}$ & $4.07 \mathrm{~B}$ & $0.33 \mathrm{~B}$ \\
\hline \multirow{4}{*}{$\mathrm{G}_{3}$} & $\mathrm{D}_{1}$ & $6.11 \mathrm{a}$ & $5.91 \mathrm{a}$ & $0.51 \mathrm{a}$ \\
\hline & $\mathrm{D}_{2}$ & $5.17 \mathrm{~b}$ & $4.87 \mathrm{~b}$ & $0.39 \mathrm{~b}$ \\
\hline & $\mathrm{D}_{3}$ & $4.25 \mathrm{c}$ & $4.03 \mathrm{c}$ & $0.31 \mathrm{c}$ \\
\hline & Mean & $5.18 \mathrm{~A}$ & $4.94 \mathrm{~A}$ & $0.40 \mathrm{~A}$ \\
\hline
\end{tabular}

Mean values in the same column for each trait with the same lower small or upper bold-case letters are not significantly different by Duncan's Multiple Range Test at $\mathrm{P} \leq 0.05 . \mathrm{G}_{1}=$ Giza 90, $\mathrm{G}_{2}=$ Giza 90 x Aust., $\mathrm{G}_{3}=$ Giza 95, $\mathrm{D}_{1}=1^{\text {st }}$ April, $\mathrm{D}_{2}=16^{\text {th }}$ April, $\mathrm{D}_{3}=1^{\text {st }}$ May.

Earliness parameters of Egyptian cotton genotypes

Earliness parameters (i.e., node of the first sympodium, days to first flower, days to first open boll and earliness index) differed significantly by planting dates and genotypes (Table 4). The first date $\left(D_{1}\right)$ had significant increases of days to first flower, days to first open boll and earliness index by $3.3 \& 7.7 \%, 2.5 \& 5.5 \%$ and $4.7 \& 13.3 \%$, respectively for Giza 90 ; by $4.0 \& 7.8 \%, 3.4 \&$ $5.7 \%$ and $4.8 \& 11.8 \%$, respectively for Giza $90 \mathrm{x}$ Aust. and by $4.1 \& 8.2 \%, 3.7 \& 5.5 \%$ and $4.3 \&$ $10.4 \%$, respectively for Giza 95 , while significant decreaseof node of the first sympodium by 14.2 $\& 24.6 \%$ for Giza 90 ; by $13.0 \& 25.0 \%$ for Giza 90 x Aust. and by $18.8 \& 22.5 \%$ for Giza 95 when compared to the second $\left(\mathrm{D}_{2}\right)$ and third $\left(\mathrm{D}_{3}\right)$ dates. For genotypes, Giza 95 was early maturity, these results achieved by significant decreases in node of the first sympodial, days to first flower and days to first open boll. In the other way there was significant increase earliness index compared to the other two genotypes.

Yield and its components of Egyptian cotton genotypes

Yield and its components (i.e., number of open bolls per plant, boll weight, seed cotton yield per feddan and lint percentage) were significant affected by planting dates and genotypes (Table 5). At the first planting date led to significant increases in the above yield and its components traits by $9.7 \& 30.7 \%, 19.0 \& 39.2 \%, 19.2 \& 86.7 \%$ and $14.9 \& 19.7 \%$, respectively for Giza 90 ; by 17.0
\& 38.6\%, $29.3 \& 55.0 \%, 22.0 \& 49.6 \%$ and 13.8 $\& 20.8 \%$, respectively for Giza $90 \times$ Aust. and by $15.1 \& 38.1 \%, 19.6 \& 47.3 \%, 20.4 \& 49.1 \%$ and $12.6 \& 23.0 \%$, respectively for Giza 95 compared to second and third planting dates.Concerning genotypes, there was significant yield and its components increases in Giza 95 compared to those in the other genotypes.

The efficiency use of heat units by Egyptian cotton genotypes

The data in Table 5 cleared that cotton plants sown in the early planting date caused a decrease in the values of heat unit efficiency for producing one open boll that means increase in efficiency use of thermal air units. This decrease was $7.74 \&$ $15.12 \%, 6.90 \& 13.86 \%$ and $5.39 \& 13.56 \%$ in the $1^{\text {th }}$ April $\left(D_{1}\right)$ for Giza 90, Giza 90 x Aust. and Giza 95 , respectively compared to the $16^{\text {th }}$ April $\left(D_{2}\right)$ and $1^{\text {st }}$ May $\left(\mathrm{D}_{3}\right)$. Giza 95 was more effective for use of thermal air units through reducing number of heat unit compared to Giza 90 x Aust. or Giza 90.

\section{Fiber properties of Egyptian cotton genotypes}

The genotypes planted in different dates demonstrated significant differences in all fiber properties, i.e., upper half mean length, fiber uniformity index, micronaire reading and fiber strength (Table 6). Cotton plants sown on $1^{\text {st }}$ April had significant increases of upper half mean length, fiber uniformity index and fiber strength by 7.8 \& $16.2 \%, 3.0 \& 5.5 \%$ and $4.4 \& 8.2 \%$, respectively for Giza 90; by $6.2 \& 14.1 \%, 1.5 \& 5.1 \%$ and $5.1 \&$ 
$8.8 \%$, respectively for Giza 90 x Aust. and by $5.6 \&$ $13.3 \%, 3.4 \& 6.1 \%$ and $6.0 \& 13.1 \%$, respectively for Giza 95, but significant decrease of micronaire reading by $9.8 \& 15.1 \%$ for Giza 90 ; by $8.5 \&$ $19.1 \%$ for Giza 90 x Aust. and by $6.8 \& 19.7 \%$ for
Giza 95 compared to plants sown on $16^{\text {th }}$ April and $1^{\text {st }}$ May. Results also showed asuperiority of Giza 95 in the above fiber properties compared to Giza 90 x Aust. and Giza 90.

TABLE 4. Effect of planting dates in combination with genotype on earliness parameters of three Egyptian cotton genotypes.

\begin{tabular}{|c|c|c|c|c|c|}
\hline $\begin{array}{l}\text { Treatments } \\
\text { genotypes (G) }\end{array}$ & Planting dates (D) & $\begin{array}{l}\text { Nodeof the } 1^{\text {st }} \\
\text { sympodium }\end{array}$ & $\begin{array}{l}\text { Days to first } \\
\text { flower }\end{array}$ & $\begin{array}{c}\text { Days to first } \\
\text { boll }\end{array}$ & Earliness index \\
\hline \multirow{4}{*}{$\mathrm{G}_{1}$} & $\mathrm{D}_{1}$ & $6.03 \mathrm{c}$ & $85.23 \mathrm{a}$ & $135.21 \mathrm{a}$ & $64.91 \mathrm{a}$ \\
\hline & $\mathrm{D}_{2}$ & $7.03 \mathrm{~b}$ & $82.51 \mathrm{~b}$ & $131.97 \mathrm{~b}$ & $62.01 \mathrm{~b}$ \\
\hline & $\mathrm{D}_{3}$ & $8.00 \mathrm{a}$ & $79.13 \mathrm{c}$ & $128.11 \mathrm{c}$ & $57.29 \mathrm{c}$ \\
\hline & Mean & $7.02 \mathrm{~A}$ & 82.29 A & $131.76 \mathrm{~A}$ & $61.40 \mathrm{C}$ \\
\hline \multirow{4}{*}{$\mathrm{G}_{2}$} & $\mathrm{D}_{1}$ & $5.23 \mathrm{c}$ & $83.29 \mathrm{a}$ & $133.17 \mathrm{a}$ & $67.09 \mathrm{a}$ \\
\hline & $\mathrm{D}_{2}$ & $6.01 \mathrm{~b}$ & $80.11 \mathrm{~b}$ & $128.79 \mathrm{~b}$ & $64.01 \mathrm{~b}$ \\
\hline & $\mathrm{D}_{3}$ & $6.97 \mathrm{a}$ & $77.27 \mathrm{c}$ & $125.95 \mathrm{c}$ & $60.01 \mathrm{c}$ \\
\hline & Mean & $6.49 \mathrm{~B}$ & 80.22 B & 129.30 B & $63.70 \mathrm{~B}$ \\
\hline \multirow{4}{*}{$\mathrm{G}_{3}$} & $\mathrm{D}_{1}$ & $4.83 \mathrm{c}$ & $81.09 \mathrm{a}$ & $130.89 \mathrm{a}$ & $69.11 \mathrm{a}$ \\
\hline & $\mathrm{D}_{2}$ & $5.95 \mathrm{~b}$ & $77.91 \mathrm{~b}$ & $126.25 \mathrm{~b}$ & $66.23 \mathrm{~b}$ \\
\hline & $\mathrm{D}_{3}$ & $6.23 \mathrm{a}$ & $74.93 \mathrm{c}$ & $124.05 \mathrm{c}$ & $62.59 \mathrm{c}$ \\
\hline & Mean & $5.67 \mathrm{C}$ & $77.98 \mathrm{C}$ & $127.06 \mathrm{C}$ & $65.98 \mathrm{~A}$ \\
\hline
\end{tabular}

Mean values in the same column for each trait with the same lower small or upper bold-case letters are not significantly different by Duncan's Multiple Range Test at $P \leq 0.05 . G_{1}=$ Giza $90, G_{2}=$ Giza 90 x Aust., $G_{3}=$ Giza 95, $D_{1}=1^{\text {st }}$ April, $D_{2}=16^{\text {th }}$ April, $D_{3}=1^{\text {st }}$ May.

TABLE 5 . Effect of planting dates in combination with genotype on yield and its components and efficiency use of heat units of three Egyptian cotton genotypes.

\begin{tabular}{|c|c|c|c|c|c|c|}
\hline $\begin{array}{l}\text { Treatments } \\
\text { genotypes } \\
\text { (G) }\end{array}$ & $\begin{array}{l}\text { Planting } \\
\text { dates (D) }\end{array}$ & $\begin{array}{l}\text { No. of open } \\
\text { bolls/plant }\end{array}$ & $\begin{array}{c}\text { Boll weight } \\
\text { (g) }\end{array}$ & $\begin{array}{l}\text { Seed cotton yield/fed } \\
\text { (Kentar) }\end{array}$ & $\begin{array}{c}\text { Lint } \\
\text { percentage }\end{array}$ & $\begin{array}{c}\text { Efficiency use of } \\
\text { heat units } \\
\text { (HU/boll) }\end{array}$ \\
\hline \multirow{4}{*}{$\mathrm{G}_{1}$} & $\mathrm{D}_{1}$ & $14.11 \mathrm{a}$ & $2.13 \mathrm{a}$ & $9.43 \mathrm{a}$ & $31.11 \mathrm{a}$ & $179.71 \mathrm{c}$ \\
\hline & $\mathrm{D}_{2}$ & $11.95 \mathrm{~b}$ & $1.79 \mathrm{~b}$ & $7.91 \mathrm{~b}$ & $27.07 \mathrm{~b}$ & $194.80 \mathrm{~b}$ \\
\hline & $\mathrm{D}_{3}$ & $10.03 \mathrm{c}$ & $1.53 \mathrm{c}$ & $5.05 \mathrm{c}$ & $26.00 \mathrm{c}$ & $211.72 \mathrm{a}$ \\
\hline & Mean & $12.03 \mathrm{C}$ & $1.82 \mathrm{C}$ & $7.46 \mathrm{C}$ & $28.06 \mathrm{C}$ & $199.06 \mathrm{~A}$ \\
\hline \multirow{4}{*}{$\mathrm{G}_{2}$} & $\mathrm{D}_{1}$ & $16.65 \mathrm{a}$ & $2.65 \mathrm{a}$ & $10.31 \mathrm{a}$ & $34.21 \mathrm{a}$ & $152.30 \mathrm{c}$ \\
\hline & $\mathrm{D}_{2}$ & $14.23 \mathrm{~b}$ & $2.05 \mathrm{~b}$ & $8.45 \mathrm{~b}$ & $30.07 \mathrm{~b}$ & $163.59 \mathrm{~b}$ \\
\hline & $\mathrm{D}_{3}$ & $12.01 \mathrm{c}$ & $1.71 \mathrm{c}$ & $6.89 \mathrm{c}$ & $28.31 \mathrm{c}$ & $176.81 \mathrm{a}$ \\
\hline & Mean & 13.12 B & $2.14 \mathrm{~B}$ & $8.55 \mathrm{~B}$ & $30.86 \mathrm{~B}$ & 177.52 B \\
\hline \multirow{4}{*}{$\mathrm{G}_{3}$} & $\mathrm{D}_{1}$ & $19.63 \mathrm{a}$ & $3.05 \mathrm{a}$ & $11.23 \mathrm{a}$ & $38.25 \mathrm{a}$ & $129.18 \mathrm{c}$ \\
\hline & $\mathrm{D}_{2}$ & $17.05 \mathrm{~b}$ & $2.55 \mathrm{~b}$ & $9.33 \mathrm{~b}$ & $33.97 \mathrm{~b}$ & $136.53 \mathrm{~b}$ \\
\hline & $\mathrm{D}_{3}$ & $14.21 \mathrm{c}$ & $2.07 \mathrm{c}$ & $7.53 \mathrm{c}$ & $31.09 \mathrm{c}$ & $149.44 \mathrm{a}$ \\
\hline & Mean & $16.96 \mathrm{~A}$ & $2.56 \mathrm{~A}$ & $9.36 \mathrm{~A}$ & $34.44 \mathrm{~A}$ & 137.32 C \\
\hline
\end{tabular}

Mean values in the same column for each trait with the same lower small or upper bold-case letters are not significantly different by Duncan's Multiple Range Test at $P \leq 0.05 . G_{1}=$ Giza 90, $G_{2}=$ Giza 90 x Aust., $G_{3}=$ Giza 95, $D_{1}=1^{\text {st }}$ April, $D_{2}=16^{\text {th }}$ April, $D_{3}=1^{\text {st }}$ May. 
TABLE 6. Effect of planting dates in combination with genotype on fiber properties of three Egyptian cotton genotypes.

\begin{tabular}{|c|c|c|c|c|c|}
\hline $\begin{array}{l}\text { Treatments } \\
\text { genotypes (G) }\end{array}$ & $\begin{array}{l}\text { Planting dates } \\
\text { (D) }\end{array}$ & $\begin{array}{l}\text { Upper half mean } \\
\text { length }(\mathrm{mm})\end{array}$ & $\begin{array}{c}\text { Fiber uniformity index } \\
(\%)\end{array}$ & $\begin{array}{l}\text { Micronaire } \\
\text { reading }\end{array}$ & $\begin{array}{l}\text { Fiber strength } \\
(\mathrm{g} / \text { tex })\end{array}$ \\
\hline \multirow{4}{*}{$\mathrm{G}_{1}$} & $\mathrm{D}_{1}$ & $31.37 \mathrm{a}$ & $81.93 \mathrm{a}$ & $3.61 \mathrm{c}$ & $47.11 \mathrm{a}$ \\
\hline & $\mathrm{D}_{2}$ & $29.09 \mathrm{~b}$ & $79.51 \mathrm{~b}$ & $4.00 \mathrm{~b}$ & $45.13 \mathrm{~b}$ \\
\hline & $\mathrm{D}_{3}$ & $27.00 \mathrm{c}$ & $77.69 \mathrm{c}$ & $4.25 \mathrm{a}$ & $43.53 \mathrm{c}$ \\
\hline & Mean & 29.15 B & $79.71 \mathrm{C}$ & $4.00 \mathrm{~A}$ & $45.26 \mathrm{C}$ \\
\hline \multirow{4}{*}{$\mathrm{G}_{2}$} & $\mathrm{D}_{1}$ & $33.21 \mathrm{a}$ & $85.29 \mathrm{a}$ & $3.21 \mathrm{c}$ & $51.13 \mathrm{a}$ \\
\hline & $\mathrm{D}_{2}$ & $31.27 \mathrm{~b}$ & $84.03 \mathrm{~b}$ & $3.51 \mathrm{~b}$ & $48.65 \mathrm{~b}$ \\
\hline & $\mathrm{D}_{3}$ & $29.11 \mathrm{c}$ & $81.15 \mathrm{c}$ & $3.97 \mathrm{a}$ & $47.00 \mathrm{c}$ \\
\hline & Mean & 30.19 B & 83.49 B & $3.56 \mathrm{~B}$ & 48.93 B \\
\hline \multirow{4}{*}{$\mathrm{G}_{3}$} & $\mathrm{D}_{1}$ & $35.23 \mathrm{a}$ & $89.17 \mathrm{a}$ & $3.01 \mathrm{c}$ & $55.31 \mathrm{a}$ \\
\hline & $\mathrm{D}_{2}$ & $33.35 \mathrm{~b}$ & $86.23 \mathrm{~b}$ & $3.23 \mathrm{~b}$ & $52.17 \mathrm{~b}$ \\
\hline & $\mathrm{D}_{3}$ & $31.09 \mathrm{c}$ & $84.01 \mathrm{c}$ & $3.75 \mathrm{a}$ & $48.91 \mathrm{c}$ \\
\hline & Mean & $33.22 \mathrm{~A}$ & 86.47 A & $3.33 \mathrm{C}$ & $52.13 \mathrm{~A}$ \\
\hline
\end{tabular}

Mean values in the same column for each trait with the same lower small or upper bold-case letters are not significantly different by Duncan's Multiple Range Test at $P \leq 0.05 . G_{1}=$ Giza 90, $G_{2}=$ Giza 90 x Aust., $G_{3}=$ Giza 95, $D_{1}=1^{\text {st }} A p r i l, D_{2}=16^{\text {th }} A p r i l, D_{3}=1^{\text {st }}$ May.

\section{Discussion}

The temperature is considered among of environmental factors determine the good growing season and enhancing adoptive potential for a specific crop. All over, global warming with ensuing elevates heat stress is a serious threat to plant growth and crop productivity (Ullah et al., 2015). Timely planting of crops is essential for root penetration and spreading, thus good vegetative growth through optimum gained of available soil nutrients and solar radiation. As environment conditions have control growth of cotton crop, so an appropriate sowing time is very essential for growers to ensure optimum yield. These results are agreed with the findings of Yucel \& Gormus (2002) because possible reasons of lowered yield are due to late planting susceptibility of cotton crop to insects and bad weather. Moreover, Gwathmey \& Clement (2010) they indicated that, late planting, usually lowers cotton yield due to delayed physiological maturity and carbohydrate deficiency.

Early planting had significant increase in the growth characteristics above mentioned compered to late planting (Table 2). This increase may be due to the decrease of air temperature and consequently the decrease of heat unit at the beginning of the season (Table 1). Early sowing exposed relatively lower air temperature and low number of heat units which allowed producing plants more tall and higher number of leaves per plant as compared to late sowing (Khan et al., 2017). The lower amounts of heat units in early season encourages the formation of more number of fruiting per plant which are the barriers of fruiting oranges that increased the fruiting capacity of cotton (Emara, 2012).

Leaf photosynthesis is an important biological process that directly influences plant growth and productivity (Wilson et al., 2012). In our results, leaf photosynthetic pigment concentrations in the leaves of cotton plants significantly increased when cotton plants were exposed to low temperature with planting on $1^{\text {st }}$ April compared to other planting dates (Table 3). These results could be explained on the base that by decreasing temperature, respiration may increase up to the optimum degree. Therefore, studying the factors affecting photosynthesis-respiration relation is a matter of great importance for crop production. Similar results were obtained by Yoon et al. (2009) and Loka \& Oosterhuis (2010).

Effects of planting dates and genotypes on earliness parameters were significant (Table 4). The early planting ( $\left(1^{\text {st }}\right.$ April) lowered significantly node of the first sympodial and delayed the appearance of first flower and first open boll compared to other planting dates, while it utilized lower number of heat units from planting to first flower. Therefore, most of the remained heat units were consumed through fruiting stage. This is situation was not achieved in case of late sowing, 
because most of the heat units were consumed in vegetative growth. Regarding, earliness percentage it tended to significant increase in favour of early planting compared to other planting dates. This might due to relatively low temperature of air and at the beginning of the season for early planting (Table 1), which directed the cotton plants to keep the balance between vegetative growth and fruiting capacity while, in late planting, the increase of air and soil temperature. Such findings are in harmony with those obtained by Hamed (2011), Ismail et al. (2012), Wenqing et al. (2012), Elayan et al. (2013) and Elayan et al. (2015).

Early planted crop produced significantly higher yield and its components than late sown crop (Table 5). Early planting crop took advantage of soil moisture and nutrients for longer growing season and produced more bolls. In contrast, late planting experienced a shorter reproductive period due to increased air temperatures and reduced canopy photosynthesis due to less radiation interception (Gormus \& Yucel, 2002 and Liu et al., 2015). Cotton plants in early planting utilized the heat units in producing the highest number of open bolls while, late planting used most of the heat units in increasing the vegetative growth. Planting cotton as early is one of the important factors which control the rank growth through the growing season and consequently increase seed cotton yield. The efficiency use of heat units by cotton plants increased in favour of early sowing rather than in late planting (Hamed, 2011). Late planting obtained the highest number of heat units and resulted in increasing of vegetative growth (Makram et al., 2001). On the other hand, late planted crop has the potential to increase cotton yield under intensive field management (Dong et al., 2006).

Cotton plants sown on $1^{\text {st }}$ April improved from fiber properties by increase of upper half mean length, fiber uniformity index and fiber strength and by decrease micronaire reading compared to plants sown on $16^{\text {th }}$ April and $1^{\text {st }}$ May (Table 6). This may be due to that early cotton sowing afforded cotton plants more vegetative growth, resulting in greater accumulation of dry matter, which enhances cotton fiber properties (Zhiguo et al., 2011). Giza 95 recorded the highest values of fiber properties compared to other genotypes. These results may be attributed to the differences among the three genotypes under study in genetical constitutions and their interaction with environmental conditions (Ismail et al., 2012).

Giza 95 variety planted early on $1^{\text {st }}$ April caused a decrease in the values of heat unit efficiency for producing one open boll that means the increase in efficiency use of thermal air units (Table 5). This could be achieved by sowing cotton in the suitable time (Emara, 2012). For early planting, most of the heat units were consumed in formation of fruiting capacity while in late planting date it was used for excessive vegetative growth. Therefore, early planting maximized the use of air heat units by increasing the efficiency use of heat units through the growing season which lowered the amount of heat units for production on boll (Elayan et al., 2006). Our data are in good agreement with Ehdaie \& Waines (2001). Finally, it is important to measure the efficiency use of heat units in cotton production, in order to maximize the use of the inputs in cotton fields.

\section{Conclusion}

This study cleared the importance of taken in consideration heat units effects on the growth and developing timing of Egyptian cotton genotypes for improving the yield quantity and quality. Therefore, in order to increase the efficiency use of the heat units through the growing season. From the results obtained, it could be generally concluded that early planting ( $1^{\text {st }}$ April) fits the Egyptian cotton genotypes particularly Giza 95 by suitable climatic window meet different developmental stages to produce higher yield by inducing a good balance between vegetative growths and fruiting capacity and maximizes the efficiency use of heat thermal units.

\section{References}

ASTM D4604-05, (2005) "Test Methods for Measurement of Cotton Fibers by High Volume Instruments (HVI) (Motion Control Fiber Information System)". Vol. 7. 02 Section 7.

Constable, G.A. and Bange, M.P. (2015) The yield potential of cotton (Gossypium hirsutum L.). Field Crops Res. 182, 98-106.

Dong, H., Li, W., Tang, W., Li, Z., Zhang, D. and Niu, Y. (2006) Yield: Quality and leaf senescence of cotton grown at varying planting dates and plant densities in the Yellow River Valley of China. Field Crops Res. 98, 106-115. 
Ehdaie, B. and Waines, J.G. (2001) Sowing date and nitrogen rate effects on dry matter and nitrogen partitioning in bread and durum wheat. Field Crops Res. 73, 47-61.

Elayan, E.D., Abd El-Hafeez, A.A., Awad, H.Y. and Hamoda, S.A.F. (2006) Effect of light intensity and heat units on earliness, yield and fiber characters of cotton varieties. J. Agric. Sci. Mansoura Univ. 31(7), 4107-4118.

Elayan, E.D., Abdallah, M., El-Sayed, A.M.A. and Abdel-Twab, R.M. (2013) Effect of some growth regulators under different planting dates on growth and yield of cotton. Bull. Fac. Agric. Cairo Univ. 64, 116-128.

Elayan, E.D., Abdallah, A.M.A., Nadia, A.S.D. and Wageda, A.E.F. (2015) Effect of delaying planting date on yield, fiber and yarn quality properties in some cultivars and promising crosses of Egyptian cotton. American-Eurasian J. Agric. \& Environ. Sci. 15(5), 754-763.

Emara, M.A.A. (2012) Response of cotton growth and productivity to application of potassium and zinc under normal and late sowing dates. J. Plant Production, Mansoura Univ. 3(3), 509-524.

Gipson, J.R. and Rayo, L.L. (1970) Temperature variety interrelationship in cotton. Grow. Rev. 47, 257-271.

Gormus, O. and Yucel, C. (2002) Different planting date and potassium fertility effects on cotton yield and fiber properties in the Cukurova region, Turkey. Field Crops Res. 78, 141-149.

Gwathmey, C.O. and Clement, J.D. (2010) Alteration of cotton source - sink relations with plant population density and mepiquat chloride. Field Crops Res. 116, 101-107.

Hamed, F.S., (2011) Air thermal units in relation to growth and development of cotton plants through different sowing dates. J. Plant Production, Mansoura Univ. 2(11), 1409-1419.

Ismail, F.M., Dewdar, M.D.H. and Mahdi, A.H.A. (2012) Multiple regression and correlation analysis of earliness and potential traits of five cotton varieties (G. barbadense L.) grown under different environments. Bull. Fac. Agric., Cairo Univ. 63, 386-395.
Khan, A., Ullah, N., Leishan, W., Daniel, K.Y.T., Guozheng, Y., Fazal, M. and Saif, Alia A., (2017) Planting density and sowing date strongly influence growth and lint yield of cotton crops. Field Crops Res. 209, 129-135.

Lichtenthaler,H.K. (1987)Chlorophylls and carotenoids: Pigments of photosynthetic biomembranes. Methods Enzymol. 148, 350-82.

Liu, J., Meng, Y., Chen, J., Lv, F., Ma, Y., Chen, B. and Oosterhuis, D.M., (2015) Effect of late planting and shading on cotton yield and fiber quality formation. Field Crops Res. 183, 1-13.

Loka, D.A. and Oosterhuis, D.M. (2010) Effect of high night temperatures on cotton respi-ration, ATP levels and car-bohydrate content. Environ-mental and Experimental Botany, 68, 258-263.

Lu, H., Dai, J., Li, W., Tang, W., Zhang, D., Eneji, A. and Dong, H. (2017) Yield and economic benefits of late planted short-season cotton versus fullseason cotton relayed with garlic. Field Crops Res. 200, 80-87.

Mahdy, E.E., Abo-Elwafa, A., Abd El-Zaher, G.H., Sayed, M.A. and Hosein, M.G. (2017) Tolerance of Egyptian cotton varieties ( $G$. barbadense L.) to late planting. Assiut J. Agric. Sci. 48(3), 34-53.

Makram, EA., Abd El-Aal, H.A., Drawish, A.A. and El-Shazly, W.M. (2001) Air the thermal units in relation to growth and development of cotton plants through different sowing dates. Minufiya J. Agric. Res. 26(3), 659-671.

Mao, L., Zhang, L., Zhao, X., Liu, S., van der Werf, W., Zhang, S., Spiertz, H. and Li, Z. (2014)Crop growth: Light utilization and yield of relay intercropped cotton asaffected by plant density and a plant growth regulator. Field Crops Res. 155, 67-76.

Sawan, M.Z. (2017) Cotton production and climatic factors: Studying the nature of its relationship by different statistical methods. Cogen. Biology, 3, $1-35$.

Snedecor, G.W. and Cochran, W.G. (1990) "Statistical Methods" $8^{\text {th }}$ ed. Iowa State Univ. Press, Ames, Iowa, U.S.A.

Ullah, K., Khan, N., Usman, Z., Ullah, R., Saleem, F., Shah, S.A.I. and Salman, M. (2015) Impact of 
temperature on yield and related traits in cotton genotypes. Journal of Integrative Agriculture Advance, 3119(15), 61088-7.

Wenqing, Z., Wang, Y., Shu, H.J. and Zhou, Z. (2012) Sowing date and boll position affected boll weight, fiber quality and fiber physiological parameters in two cotton (Gossypium hirsutum L.) cultivars. African J. Agric., Res. 7(45), 6073-6081.

Wilson, C., Dafeng, H., Emeka, N., Jun, W., Qi, D., Desh, D. and Fisseha, T. (2012) Effects of planting dates, densities and varieties on ecophysiology of pigeonpea in the southeastern united states. Agricultural Sciences, 3(2), 147-152.

Yeates, S.J., Kahl, M.F., Dougall, A.J. and Müller, W.J. (2013) The Impact of variable, cold minimum temperatures on boll retention, boll growth and yield recovery of cotton. The Journal of Cotton Science, 17, 89-101.

Yoon, S.T., Hoogenboom, G., Flitcroft, I. and Bannayan, M. (2009) Growth and develop-ment of cotton (Gossypium hirsutum L.) in response to $\mathrm{CO}_{2}$ enrichment under two different temperature regimes. Environmental and Experimental Botany, 67, 178-187.

Young, E.F., Teler, R.M. and Petarson, H.D. (1980) Day-degree units and time in relation to vegetative development and fruiting for three cultivars of cotton. Crop Sci. 20, 370-375.

Yucel, C. and Gormus, O. (2002) Different planting date and potassium fertility effects on cotton yield and fiber properties in the Cukurova region, Turkey. Field Crops Research, 78, 141-149.

Zhiguo, Z.Y., Meng, W.Y., Oosterhuis, D.M. and Shu, H. (2011) Effect of planting date and boll position on fiber strength of cotton (Gossypium hirsutum L.). Amer. J. Experimental Agric. 1(4), 331-342.

(Received 16/4/2019; accepted 31/7 /2019)

$$
\begin{aligned}
& \text { تقييم أداء ثلاثة تراكيب وراثية من القطن المصرى تحت وحدات حرارية مختلفة من خلال } \\
& \text { مواعيا زراعة مختلفة }
\end{aligned}
$$

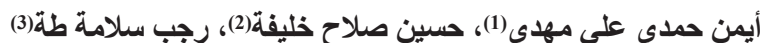

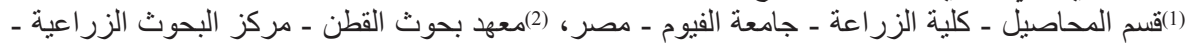

$$
\begin{aligned}
& \text { الجيزة ـ مصر، (3)قسم النبات الزر اعي ـ كلية الزر اعة - جامعة الفيوم - مصر. }
\end{aligned}
$$

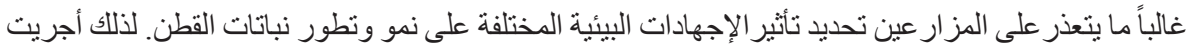

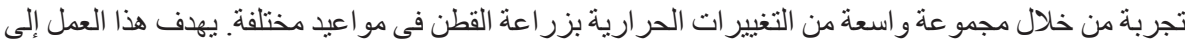

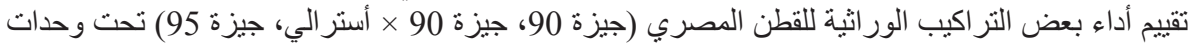

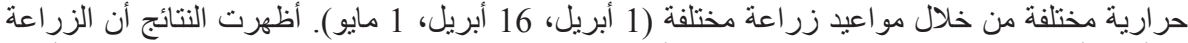

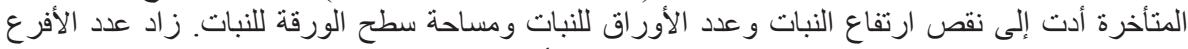

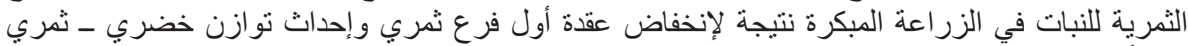

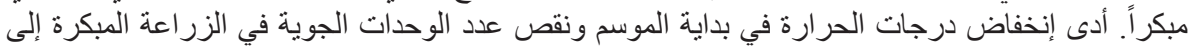

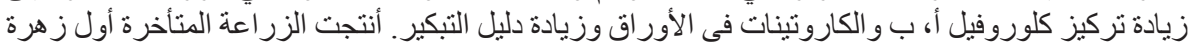

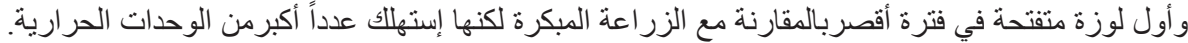

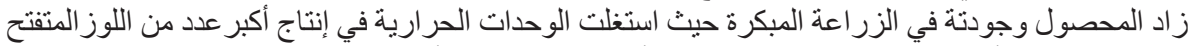

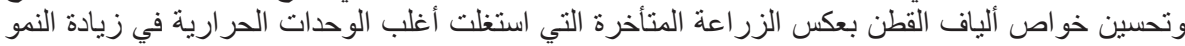

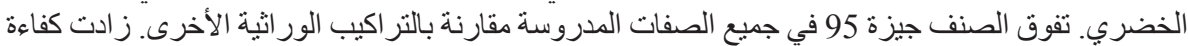

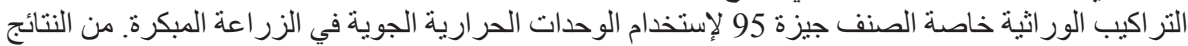

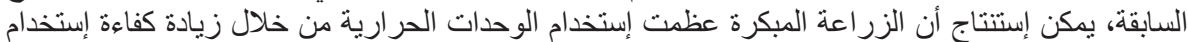

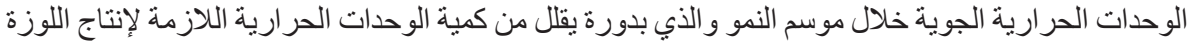

$$
\text { الو احدة. }
$$

